\title{
Prediction of Explosive Power of Basketball Players Based on their Morpho-Functional Characteristics
}

\author{
Predicción de la Potencia Explosiva de los Jugadores de Baloncesto \\ en Función de sus Características Morfofuncionales
}

*Agron M. Rexhepi; **Behlul Brestovci \& ***Azbije Mucolli

REXHEPI, A. M.; BRESTOVCI, B. \& MUCOLLI, A. Prediction of explosive power of basketball players based on their morphofunctional characteristics. Int. J. Morphol., 30(2):719-722, 2012.

SUMMARY: The aim of this study was to define the morpho-functional variables that best predict the explosive power of the lower extremities of basketball players of Kosova. On 113 basketball players average aged 21.3 years old, 15 morpho-functional variables were measured: Stature, Body Weight, Humeral Perimeter, Chest Perimeter, Abdominal Perimeter, Thigh Perimeter, Calf Perimeter, Triceps Skinfold, Subscapular Skinfold, Abdominal Skinfold, Thigh Skinfold, Calf Skinfold, Heart Rate, VO2max.rel., and Explosive Power that was tested through Margaria-Kalamen Test. All tested basketball players are competitors in the Super League of Kosova. Linear regression of the data indicates that the system of 13 morpho-functional predictive variables explains $62.5 \%$ of total variability of the dependant variable. The variables that indicate positive influence on dependant variable - explosive power of the lower extremities are: Thigh Perimeter $(\mathrm{b}=.413)$, Chest Perimeter $(\mathrm{b}=.316)$, and Heart Rate $(-2.01)$. According to the results of this study, one can conclude that basketball players with higher values of the volume of thighs, with balanced muscles and core stability, as well with low rate of heart frequency during resting period, will have higher explosive power of the lower extremities. So, the conditional coaches, during the training with the young basketball players, should pay more attention to develop these morphometrical variables.

KEY WORDS: Regressive analyses; Perimeter; Muscles; Thighs.

\section{INTRODUCTION}

Basketball is one of the most popular sports games, played by two opposing teams. The aim of the game is for each team to defend a goal area while trying to score goals at the opposing end of the court. For optimal performance during play at an elite level a variety of areas must be addressed. These include the high skill level, flexibility, muscular strength, endurance and importantly the specific use of both the aerobic and anaerobic energy systems. The specific requirements do vary depending on the level of competition. The average works intensity of basketball game is above $80 \%$ of $\mathrm{VO}_{2} \max$, respectively above $85 \%$ of maximal heart rate (Balciunas et al., 2006; Nudri et al., 1996; McInes et al., 1995; Reilly \& Williams, 2005). This combination of energy requirements is often referred to as an integration of energy supply systems on a continuum over time (Narazaki et al., 2009).

Many factors contribute to the performance of the basketball athlete. This includes a combination of technical and tactical abilities that are duties of coaching staff, as well as a high degree of physical fitness that is more relevant for sports medicine and exercise trained staff.

Morpho-functional testing provides an assessment of morpho-functional status which can be used as a measure of sports performance (McDougall et al., 1991).

Anthropometry is used to provide a basis for training and dietary interventions. This includes measurements of age, height, mass and skinfolds. Even if, the basketballers have varying anthropometric characteristics depending on their position of the player, most of elite basketballers have tall muscular and well balanced physiques.

Anaerobic performance tests are used to assess speed, acceleration, explosiveness and repeated short bursts of efforts which as indicated are all important components of basketball. Among other functional tests, Margaria-Kalamen

* Sport Center for Increasing of Morpho-Functional Abilities, Fitness and Nutrition "Corpore Sano", Pristina, Kosovo

** Faculty of Special Education and Rehabilitation, University of Zagreb, Zagreb, Croatia.

*** Primary school "Daradania"; Pillates studio A@E, Pristina, Kosovo. 
test is familiar test within the literature to measure explosive power of the lower extremities of the sportsmen.

Aerobic power is another important component of the basketball sport game. Continuous periods of effort are required throughout a full length game and more so within a heavy training session which must utilize oxygen for performance. The maximal oxygen consumption $\left(\mathrm{VO}_{2} \max \right)$ test is the common test for assessment of aerobic power. Muscular force is the maximum amount of force that a muscle or muscle group can exert (McArdle et al., 1996; Power \& Howley, 2001).

Jumping ability of the basketball players depends on their strong thigh and calf muscles. Players need to have strong hips to hyperextend their legs and propel the body forward as well. Also, a basketball player to attain a balanced body needs to build the strong muscles of the body (abdominal, upper bodies, as well upper extremities muscles).

Even if, the explosive force of athletes is highly determinate by the genetic factor, if the external factors affect in athletes in adequate time, with adequate stimulus, their explosive force may be increased, or at least may be developed till their maximum (Rexhepi, 2009).

Perimeters of the limbs and trunk are occasionally used as relative indicators of muscularity, whereas skinfold thickness is an indicator of subcutaneous adipose tissue. Skinfolds measures are the major determinant of body fat and are generally used as a basis for training and dietary interventions. As basketball is a sport requiring speed and explosive power, excess fat is undesirable as it will be detrimental to performance.

The aim of this study was to define the morphofunctional variables that best predict an explosive power of the lower extremities of the basketball players of Kosova.

\section{MATERIAL AND METHOD}

This study is a part of the project titled: "Morphofunctional abilities of the athletes from Kosova", being carried out at the Center for Sport Medicine and Recreation in Prishtina, Kosovo.

The procedures followed during the measurements of the sportsmen were in accordance with the ethical standards of the ethics committee of University Clinical Center.
In this study 15 morpho-functional variables are measured on 113 basketball players, with an average age of 21.3 years (17-34 years old). All of them are players of the Super League of Kosova. Because, stature, body weight, and metabolism show diurnal variation, the basketball players were measured in the morning hours 08.00 - 11.00 AM (Ellis et al., 1998; Lupash, 2009).

The following variables were measured:

1. Stature (expressed in $\mathrm{mm}$ ): Body height measures the distance from the standing surface to the top (vertex) of the skull.

2. Body Weight (expressed in $\mathrm{kg}$ ).

3. Humeral Perimeter (expressed in $\mathrm{mm}$ ): shows maximum circumference of the arm (humerus).

4. Chest Perimeter (expressed in $\mathrm{mm}$ ): shows maximum circumference of the thorax at the mammilla level.

5. Abdominal Perimeter (expressed in $\mathrm{mm}$ ): shows circumference of the abdomen at the umbilicus level.

6. Thigh Perimeter (expressed in $\mathrm{mm}$ ): shows maximum circumference of the thigh.

7. Calf Perimeter (expressed in $\mathrm{mm}$ ): shows maximum circumference of the calf.

8. Skinfold thickness variables (expressed in $\mathrm{mm}$ ):

9. Triceps Skinfold: shows subcutaneous adipose tissue on the back of the arm (humerus) over the triceps muscle.

10. Subscapular Skinfold: shows subcutaneous adipose tissue on the back just below the inferior angle of scapula.

11. Abdominal Skinfold: shows subcutaneous adipose tissue of the abdomen at the umbilicus level $5 \mathrm{~cm}$ on the left.

12. Thigh Skinfold: shows subcutaneous adipose tissue on the thigh.

13. Calf Skinfold: shows subcutaneous adipose tissue on the calf, measured at the same level like calf's perimeter.

14. Heart rate: shows the number of heart beats per minute (bpm).

$\mathrm{VO}_{2}$ max.rel. - describes the maximum amount of oxygen that an athlete utilizes during highly intense aerobic exercise. It is expressed in milliliters per kilogram of body weight per minute $(\mathrm{ml} / \mathrm{kg} / \mathrm{min})$. In this study this variable has been recorded during the Astrand Bike Test (according to the value of the athlete's heart rate on 5th minute of this test).

Power test (Margaria Kalamen Power test) - was used to test the explosive power of the lower extremities.

Anthropometric variables were measured by the classical anthropometric instruments, according to the definitions of International Biological Program.

The obtained results were analyzed in terms of descriptive statistic, Correlation Analyses, and Regressive Analyses. The measurements were done in the Center of Sports Medicine and Recreation in Prishtina, Kosova, during the period $2008-2009$. 


\section{RESULTS}

Table I. Descriptive Statistics.

\begin{tabular}{lccccc}
\hline Variables & $\mathbf{n}$ & Mini & Maxi & Mean & Std. Dev. \\
\hline Age & 113 & 17.00 & 34.00 & 21.28 & 4.04 \\
Stature & 113 & 1703.00 & 2046.00 & 1916.45 & 77.30 \\
Body weight & 113 & 51.50 & 113.70 & 83.70 & 10.81 \\
Humeral Perimeter & 113 & 230.00 & 358.00 & 296.46 & 28.40 \\
Chest Perimeter & 113 & 785.00 & 1127.00 & 971.59 & 61.11 \\
Abdominal Perimeter & 113 & 670.00 & 1003.00 & 846.46 & 62.55 \\
Thigh Perimeter & 113 & 470.00 & 697.00 & 579.93 & 42.53 \\
Calf Perimeter & 113 & 316.00 & 616.00 & 395.73 & 37.66 \\
Humeral Skinfold & 113 & 32.00 & 260.00 & 89.36 & 40.40 \\
Subscapular Skinfold & 113 & 42.00 & 212.00 & 87.76 & 31.66 \\
Abdominal Skinfold & 113 & 40.00 & 348.00 & 106.33 & 62.64 \\
Thigh Skinfold & 113 & 40.00 & 362.00 & 113.01 & 61.84 \\
Calf Skinfold & 113 & 32.00 & 320.00 & 82.50 & 37.99 \\
Heart Rate & 113 & 50.00 & 100.00 & 69.88 & 11.23 \\
VO 2 max.rel. & 113 & 28.60 & 62.50 & 45.79 & 6.12 \\
Power test & 113 & 105.33 & 216.28 & 163.94 & 22.96 \\
\hline
\end{tabular}

Table II. Regression Analyses. a. Independent Variables: $\mathrm{VO}_{2}$ max.rel., Heart Rate, Thigh Skinfold, Calf Perimeter, Chest Perimeter, Stature, Calf Skinfold, Thigh Perimeter, Abdominal Skinfold, Humeral Perimeter, Abdominal Perimeter, Humeral Skinfold, Subscapular Skinfold; b. Dependent Variable: PowerTest.

\begin{tabular}{lcccccc}
\hline Model & $\mathbf{R}$ & $\mathbf{R}^{2}$ & Adjusted R2 & $\begin{array}{c}\text { Std. Error of the } \\
\text { Estimate }\end{array}$ & F & Sig. \\
\hline $\mathbf{1}$ & .825 & .688 & .625 & 14.057 & 11.004 & .000
\end{tabular}

Table III. Beta Coefficients, Correlations (R), and Partial Correlations (PR). a. Dependent Variable: PowerTest

\begin{tabular}{lccccc}
\hline Variables & $\mathbf{R}$ & $\mathbf{P R}$ & Beta & $\mathbf{t}$ & Sig. \\
\hline Stature & $* * .314$ & .000 & .000 & -.002 & .998 \\
Humeral Perimeter & $* * .672$ & .058 & .083 & .470 & .640 \\
Chest Perimeter & $* * .716$ & $* .262$ & $* .316$ & $* 2.187$ & .032 \\
Abdominal Perimeter & $* * .543$ & .090 & .108 & .725 & .471 \\
Thigh Perimeter & $* * .621$ & $* * .331$ & $* .413$ & $* 2.827$ & $* .006$ \\
Calf Perimeter & $* * .327$ & -.096 & -.065 & -.774 & .442 \\
Humeral Skinfold & .096 & -.038 & -.051 & -.305 & .761 \\
Subscapular Skinfold & $* .254$ & .186 & .298 & 1.525 & .132 \\
Abdominal Skinfold & .178 & -.181 & -.271 & -1.485 & .142 \\
Thigh Skinfold & .019 & -.165 & -.199 & -1.347 & .183 \\
Calf Skinfold & -.212 & -.235 & -.207 & -1.948 & .056 \\
Heart Rate & $* *-.295$ & $*-.242$ & $*-.157$ & $*-2.010$ & $* .049$ \\
VO ${ }_{2 \text { max.rel }}$ & $*-.235$ & -.013 & -.011 & -.105 & .917 \\
\hline
\end{tabular}

*Correlation is significant at the 0.05 level (2-tailed). **Correlation is significant at the 0.01 level (2-tailed).
On Table I are shown descriptive parameters (mini-mum, maximum, and mean values, as well standard de-viation) of measured variables.

Table II shows the main data of the Regression Analyses, according to which we can conclude if the system of the independent variables (measured morphofunctional variables) significantly can predict dependent variable (explosive power).

Table III contains the values of the Beta Coefficients for each measured independent variable, as well their t-test and significance. Also this table contains results of correlation (R) and partial correlation (PR) that realized each independent variable with dependant variable. Because the variable Body Weight is integrated in dependent variable (Power Test), it was eliminated from the system of predictive variables. According to the values of the Beta Coefficients we can extract the independent variables that significantly can predict the values of the explosive power as dependent variable.

\section{DISCUSSION}

Basketball is a team sport game that requires explosive power of the lower extremities, as well as multiple high intensity sprint type efforts throughout the game and especially at training.

Physiological exercise testing is important in basketball sport game to help trainers and coaching staff with some profiles for the players.

Based on the results of the linear regression, shown on Table II, can be concluded that the system of 13 morpho-functional independent (predictive) variables explains $62.5 \%$ 
of the total variability of the dependant variable (Explosive Power), with lower standard error of the estimate $=14.1$.

Inside the system of independent variables, almost, all measured variables (except variables that inform about adipose tissue) show significant correlation with explosive power of the basketball players. Based on the partial correlation (PR) that each independent variable realized with explosive power (without influence of other measured variables), may be extracted three variables that realized significant partial correlation. Thigh Perimeter and Chest Perimeter have realized positive correlation with dependant variable, whereas Heart Rate has realized negative correlation. Statistically the findings of the partial correlation strongly support the findings of the linear regression (Table III).
The variables that indicate positive influence on dependant variable - explosive power of the lower extremities (Table III) are two morphometric variables: Thigh Perimeter $(b=.413)$, and Chest Perimeter $(b=.316)$, while Heart Rate shows negative influence on dependant variable (-2.01).

According to the results of this study, one can conclude that the basketball players with the higher values of the body volume - especially volume of thighs, with the balanced muscles and the core stability, as well with low rate of the heart frequency during the resting period, will have the higher explosive power of the lower extremities that is very important for the basketball game. So, it may be suggested that the conditional coaches, during the trainings with the young basketball players, should pay more attention to develop these morphometrical variables.

REXHEPI, A. M.; BRESTOVCI, B. \& MUCOLLI, A. Predicción de la potencia explosiva de los jugadores de baloncesto en función de sus características morfofuncionales. Int. J. Morphol., 30(2):719-722, 2012

RESUMEN: El objetivo de este estudio fue definir las variables morfofuncionales que mejor predicen la potencia explosiva de los miembros inferiores de los jugadores de baloncesto de Kosovo. En 113 años jugadores de baloncesto con una edad promedio de 21,3 años, se midieron 15 variables morfofuncionales: estatura, peso corporal, perímetro del húmero, perímetro torácico, perímetro abdominal, perímetro del muslo, perímetro de la pierna, pliegue del tríceps, pliegue subescapular, pliegue abdominal, pliegues cutáneos del muslo, pliegues cutáneos de la pierna, frecuencia cardíaca, $\mathrm{VO}_{2}$ max.rel, y el poder explosivo que fue probado a través de prueba Margaria-Kalamen. Todos los jugadores de baloncesto evaluados son jugadores de la Súper Liga de Kosovo. La regresión lineal de los datos indica que el sistema de 13 variables morfofuncionales predictoras explica el 62,5\% de la variabilidad total de la variable dependiente. Las variables que indican una influencia positiva sobre la variable dependiente - potencia explosiva de los miembros inferiores son los siguientes: el perímetro del muslo $(b=$ 0,413), perímetro torácico $(b=0,316)$, y la frecuencia cardíaca $(-2,01)$. De acuerdo con los resultados de este estudio, se puede concluir que los jugadores de baloncesto con los valores más altos del volumen de los muslos, con los músculos equilibrados y la estabilidad de núcleo, así como con bajo índice de la frecuencia cardíaca durante el período de descanso, tendrán la mayor potencia explosiva de los miembros inferiores. Por lo tanto, los entrenadores durante los entrenamientos con los jóvenes jugadores de baloncesto, deberían prestar más atención al desarrollo de estas variables morfométricas.

PALABRAS CLAVE: Análisis regresivo; Perímetro; Músculos; Muslos.

\section{REFERENCES}

Balciunas, M.; Stonkus, S.; Abrantes, C. \& Sampaio, J. Long term effects of different training modalities on power, speed, skill and anaerobic capacity in young male basketball players. J. Sport Sci. Med., 5:163-70, 2006.

Ellis, L.; Gastin, P.; Lawrence, S.; Savage, B. \& Sheales, A. Testing protocols for the physiological assessment of team sport players. In: Gore, J. (Ed.). Test Methods Manual. 3rd Ed. Canberra, Australian Sports Commission, 1998.

Lupash, E. Acsm's guidelines for exercise testing and prescription. American College of Sports Medicine. 7th Ed. Baltimore, Lippincott Williams \& Wilkins, 2009.

McArdle, W. D.; Katch, F. I. \& Katch, V. L. Exercise physiology. 4th Ed. Baltimore, Maryland, Lippincott Williams\& Wilkins, 1996.

McDougall, J. D.; Wenger, H. A. \& Green, H. J. The Purpose of Physiological Testing. In: Physiological Testing of the High Performance Athlete. Illinois, Human Kinetics Books, 1991. pp.1-6.

McInnes, S. E.; Carlson, J. S.; Jones, C. J. \& McKenna, M. J. The physiological load imposed on basketball players during competition. J. Sports Sci., 13(5):387-97, 1995.
Narazaki, K.; Berg, K.; Stergiou, N. \& Chen, B. Physiological demands of competitive basketball. Scand. J. Med. Sci. Sports, 19(3):425$32,2009$.

Nudri, W. D.; Ismail, M. N. \& Zawiak. H. Anthropometric measurements and body composition of selected national athletes. Mal. J. Nutr., 2(2):138-47, 1996.

Power, K. S. \& Howley, T. E. Exercise Physiology. 4th ed. New York, McGraw Hill, 2001.

Reilly, T. \& Williams, M. A. Science and soccer. 2nd ed. New York, Routledge, 2005. pp.287-301.

Rexhepi, A. Textbook Mjekësia Sportive-Sports Medicine. Prishtina, Mozaiku, 2009. pp.276-9.

Correspondence to:

Agron Rexhepi

Sport Center for Increasing of Morpho-Functional Abilities

Fitness and Nutrition "Corpore Sano"

Str. "Sali Butka" Nr. 31/D, 10020 Pristina

KOSOVO

Email: agronmrexhepi@gmail.com

Received: 30-08-2011

Accepted: 29-02-2012 